\title{
LAMA PENYIMPANAN TERHADAP PERKECAMBAHAN BIJI CABAI RAWIT
}

\author{
Irwan Sombalatu ${ }^{1}$, Irvan Lasaiba ${ }^{2}$, Evi Ristiana ${ }^{3}$ \\ ${ }^{1,2}$ Program Studi Pendidikan Biologi IAIN Ambon \\ ${ }^{3}$ Program Studi Pendidikan Biologi UNISMUH Makassar \\ E-mail: irwan_sombalatu@yahoo.co.id
}

\begin{abstract}
Abstrak: Tanaman cabai merupakan holikurtural yang bibitnya berasal dari biji yang banyak dibudidayakan oleh para petani cabai rawit, namun pada akhir-akhir ini terjadi perlonjakan harga signifikan di pasar. Di Indonesia sayuran hampir dijumpai disemua masakan, terutama pada masyarakat pedesaan. Cabai yang merupakan sayuran buah kebanyakan ditemui dalam masakan Indonesia, membuktikan bahwa masyarakat Indonesia sangat menyukai cabai. Tetapi mengenai asal usul cabai masuk ke Indonesia belum ada data yang menyebutkan secara pasti.Penelitian ini bertujuan untuk mengetahui pengaruh lama penyimpanan terhadap perkecamnahan biji cabai rawit (Capsicum frutescens L). Hasil penelitian menunjukan bahwa adanya pengaruh lama waktu penyimpanan 6 hari terhadap perkecambahan biji cabai rawit dengan nilai $(88,3333 \%)$ yang merupakan perkecambahan yang baik dalam penelitian ini, namun tidak menunjukan laju perkecambahan pada perlakuan tersebut.
\end{abstract}

\section{Kata Kunci: Penyimpanan, Perkecambahan, Cabai Rawit}

Di Indonesia sayuran hampir dijumpai disemua masakan, terutama pada masyarakat pedesaan. Cabai yang merupakan sayuran buah kebanyakan ditemui dalam masakan Indonesia, membuktikan bahwa masyarakat Indonesia sangat menyukai cabai. Tetapi mengenai asal usul cabai masuk ke Indonesia belum ada data yang menyebutkan secara pasti. Menurut dugaan, kemungkinan besar cabai dibawa oleh saudagar-saudagar dari Persia ketika singgah di Aceh. Sumber lain yang menyebutkan bahwa cabai masuk ke Indonesia karena dibawa oleh bangsa portugis (Ihsanul Arifin, 2010).

Cabai pada dasarnya terdiri atas dua golongan utama yaitu cabai besar (Camsicum annum L) dan cabai rawit (Capsicum frutescens $\mathrm{L}$ ). Cabai besar terdiri atas cabai merah (hot pepper/cabai pedas), cabai hijau, dan paparika (sweet pepper). Cabai merah besar terdiri dari hibrida dan nonhibrida. Cabai rawit pun banyak ragam dan biasanya merupakan cabai lokal yang bukan hibrida. Selain berguna sebagai bahan penyedap masakan, cabai mengandung protein, lemak, karbohidrat, kalsium $(\mathrm{Ca})$, posfor $(\mathrm{P})$, besi $(\mathrm{Fe})$. Vitamin-vitamin (salah satunya adalah vitamin $\mathrm{C}$ ) dan mengandung senyawasenyawa alkaloid, seperti kapsaisin, flavonoid, dan minyak esesial (Almatsier, 2004).

Tanaman cabai merupakan holikurtural yang bibitnya berasal dari biji yang banyak dibudidayakan oleh para petani cabai rawit, namun pada akhir-akhir ini terjadi perlonjakan harga signifikan di pasar. Kenaikan harga cabai dipenghujung tahun 2010 
yang lalu kemugkinannya hanya disebabkan oleh satu hal, yakni pergeseran titik keseimbangan harga yang diakibatkan oleh pergeseran supply dan demand cabe dipasar. Untuk kasus 2010 lebih cenderung diakibatkan bergesernya pasokan (supply) cabai ke pasar sehingga mendorong kenaikan harga di pasar. Pergesekan pasokan cabai (berkurangnya dan cenderung langkah) di pasar diakibatkan oleh terganguhnya produksi yang dialami para petani yang diakibatkan oleh bergesernya perubahan cuaca yang menggangu pola dan kualitas produksi cabe. Perubahan cuaca ini sangat bergantung pada khususnya kelembapan udara dan kadar air tanah. Selain tergangguhnya cabai yang terjadi diakhir tahun 2010, penyebab lain kenaikan komoditas cabai ini juga disebabkan oleh tergangguhnya distribusi komoditas cabe ke pasar. Tergantungnya distribusi tersebut lebih cenderung merupakan gangguan distribusi yang disengaja oleh segelintir pelaku pasar.

Gangguan distribusi ini lebih cenderung diakibatkan oleh ulang tengkulak yang sengaja mengambil kesempatan atau untung ditengah kenaikan komoditas cabe. Akan tetapi faktor ini tidak terlalau singnifikan mempengaruhi kenaikan harga cabai dibandingkan dengan produksi yang terganggu, ini dikarenakan cabai bukanlah komoditas yang sifatnya tahan lama sehingga para tengkulakpun (spekulan) tidak akan berani menahan pasokan cabai dalam kuantitas banyak dan waktu yang lama. Gangguan terhadap pola dan kuantitas produksi yang terjadi pada komoditas cabe yang terjadi pada akhir tahun 2010 ini bukanlah kejadian yang sulit dan tidak bisa diprediksi. Jika dilihat dari pergeseran dan perubahan iklim yang cenderung ekstrim beberepa tahun belakang ini, sudah bisa dengan pasti diperdiksikan akan mengangguh pola dan kualitas komoditas pertanian dan begitu juga dengan tanaman cabe. Karakteristik tanaman cabai yang juga bergantung kepada kelembapan udara dan kualitas kandungan air dalam tanah serta perubahan iklim atau cuaca tahun belakangan ini, sudah bisa menjadi dasar untuk melakukan prediksi bahwa kondisi ini akan menganggu produksi tanaman cabai. Prediksi dini inilah yang tidak bisa dilakukan oleh pemerintah melalui instansi yang terkait (kementrian pertanian dan perdagangan). Kelemahan prediksi ini berunjung kepada ketidak siapaan pemerintah menghadapi kondisi saat ini sehingga berujung kepada kenaikan harga komoditas cabe yang mencapai lebih dari 127 persen

\section{METODE PENELITIAN}

Tipe penelitian yang digunakan dalam penelitian ini adalah eksperimen lapangan dengan mengunakan rancangan acak kelompok (RAK) dengan pola 4 x 3 yang terdiri dari 4 perlakuan dan 3 kelompok ulangan, sehingga terdapan 12 unit pengamatan.

Tabel 1. Rancangan Penelitian

\begin{tabular}{|c|c|c|c|c|c|}
\hline \multirow{2}{*}{ Perlakuan } & \multicolumn{3}{|c|}{ Kelompok } & \multirow{2}{*}{ Jumlah } & \multirow{2}{*}{ Rata- rata } \\
\cline { 2 - 4 } & $\mathrm{I}$ & $\mathrm{II}$ & $\mathrm{III}$ & & \\
\hline $\mathrm{X}_{0}$ & $\mathrm{X}_{0} 1$ & $\mathrm{X}_{0} 2$ & $\mathrm{X}_{0} 3$ & $\sum \mathrm{Y}_{0}$ & $\mathrm{Y}_{0}$ \\
\hline $\mathrm{X}_{1}$ & $\mathrm{X}_{1} 1$ & $\mathrm{X}_{1} 2$ & $\mathrm{X}_{1} 3$ & $\sum \mathrm{Y}_{1}$ & $\mathrm{Y}_{1}$ \\
\hline
\end{tabular}

BIOLOGI SEI (YOL 6 NO 2 EDISI JUL-DES 2017 ISSN 2252-858X/E-ISSN 2541-1225) PAGE 139 


\begin{tabular}{|c|c|c|c|c|c|}
\hline $\mathrm{X}_{2}$ & $\mathrm{X}_{2} 1$ & $\mathrm{X}_{2} 2$ & $\mathrm{X}_{2} 3$ & $\sum \mathrm{Y}_{2}$ & $\mathrm{Y}_{2}$ \\
\hline $\mathrm{X}_{3}$ & $\mathrm{X}_{3} 1$ & $\mathrm{X}_{3} 2$ & $\mathrm{X}_{3} 3$ & $\sum \mathrm{Y}_{3}$ & $\mathrm{Y}_{3}$ \\
\hline Total & & & & $y_{\mathrm{ij}}$ & $\bar{y}$ \\
\hline
\end{tabular}

Keterangan

$\mathrm{X}_{0}=$ Control (Tanpa Perlakuan)

$\mathrm{X}_{1}=$ Lama penyimpanan selama 3 hari

$\mathrm{X}_{2}=$ Lama penyimpanan selama 6 hari

$\mathrm{X}_{3}=$ Lama penyimpanan selama 9 hari

Variabel yang digunakan dalam penelitian terdiri dari: Variabel bebas (X) yaitu lama penyimpanan dan variabel terkait $(\mathrm{Y})$ yaitu perkecambahan biji cabai rawit.

\section{Persiapan benih cabai rawit}

Benih cabai rawit yang disiapkan adalah benih yang baik dan terhindar dari hama dan penyakit, setelah itu diambil bijinya lalu dicuci mengunakan aquades dan dikeringkan, selanjutnya benih cabai rawit ditimbang mengunakan timbangan elektrik untuk mengetahui berat rata-rata dari biji cabai rawit yang digunakan sebagai bahan penelitian.

\section{Cara penyimpanan benih}

Mengambil biji cabai sebanyak 30 biji, untuk perlakuan pertama, kedua dan ketiga, untuk masing-masing cawan petri berisi 10 biji cabai rawit, kemudian diletakan ke dalam cawan petri, lalu disimpan didalam cawan petri selama 9 hari secara keseluruhan dengan jeda waktu perlakuannya itu selama 3 hari. Untuk diketahui perlakuan pertama, kedua dan ketiga ditanam pada hari ke 0 setelah diangkat dari dalam ruang penyimpanan, dan dari semua perlakuan itu dipindahkan pada media tanam yang baru untuk melihat presentase perkecambahan dan laju perkecambahannya.

\section{Menyiapkan media tanam.}

Sebelum tanah dimasukkan ke dalam polybag, tanah yang didapatkan harus diolah terlebih dahulu diayak dan digemburkan karena masih banyak mengandung batu, potongan kayu dan kotoran lainya agar dapat memenuhi syarat media tanam cabai rawit dalam polybag (ukuran 30 x30 cm).

\section{Menyamai benih.}

Penyamaian benih dilakuan dengan cara penaburan benih diatas permukaan media pesemain, penyemaian benih atau biji cabai dilakuan pada polybag

\section{Memelihara benih atau biji cabai rawit}

Pemeliharaan bibit ini meliputi penyiraman dan pengendalian hama penyakit. Penyiraman dilakukan setiap 2 hari sekali secara merata keseluruh permukaan polybag, jumlah air disesuaikan dengan keadaan tanah. Jangan terlalu basah dan jangan terlalu kering.

\section{Presentase perkecambahan $\%$}

Presentase perkecambahan menunjukan jumlah biji yang berkecambah yang diperkecambahkan pada masing-masing perlakuan selama 20 hari 
$\%$ Perkecambahan $=\frac{\text { Jumlah biji yang berkecambah }}{\text { Total biji yang dikecambahkan }} \times 100 \%$

\section{Laju perkecambahan}

Adalah perbandingan jumlah biji yang berkecambah pada hari tertentu dengan waktu yang bersesuian yang didasarkan pada indeks vigor, dengan rumus:

$\mathrm{I} . \mathrm{V}=\frac{G I}{D I}+\frac{G 2}{D 2}+\ldots \ldots \cdot \frac{G n}{D n}$

Keterangan:

I.V = indeks vigor

$\mathrm{G} \quad=$ jumlah biji yang berkecambah

D = waktu yang bersesuaian dengan jumlah tersebut.

Analisis statistik deskriptif yaitu untuk mengambarkan perkecambahan biji cabai rawit. Analisis statistik inferensial yaitu untuk mengetahui perbedaan pengaruh masingmasing perlakuan dengan mengunakan analisis sidik ragam (Uji F)

\section{HASIL DAN PEMBAHASAN}

\section{Presentase Perkecambahan Biji Cabai Rawit}

Hasil penelitian perkecambahan biji cabai rawit menunjuhkan bahwa ada pengaruh terhadap masing-masing perlakuan sebagaimana pada tabel dibawah ini Tabel 2. Presentase perkecambahan biji cabai rawit terhadap berbagai lama penyimpanan.

\begin{tabular}{|c|c|c|c|c|c|}
\hline Perlakuan & \multicolumn{3}{|c|}{ Kelompok } & \multirow{2}{*}{ Rumlah (\%) } & \multirow{2}{*}{ Rata\% } \\
\hline $\mathrm{X}_{0}$ & $\mathrm{I}$ & $\mathrm{II}$ & III & & 56,66667 \\
\hline $\mathrm{X}_{1}$ & 50 & 60 & 60 & 170 & 70 \\
\hline $\mathrm{X}_{2}$ & 70 & 70 & 70 & 210 & 88,33333 \\
\hline $\mathrm{X}_{3}$ & 80 & 90 & 80 & 250 & 66,66667 \\
\hline Total & 270 & 60 & 70 & 200 & 69,16667 \\
\hline
\end{tabular}

Sumber: Data Penelitian.

Presentase perkecambahan biji cabai rawit akibat perlakuan lama penyimpanan, yang menunjuhkan adanya perlakuan tertentu yang sangat berpengaruh sangat nyata yaitu pada lama penyimpanan 6 hari. Lebih jelas dapat dilihat pada grafik berikut. 


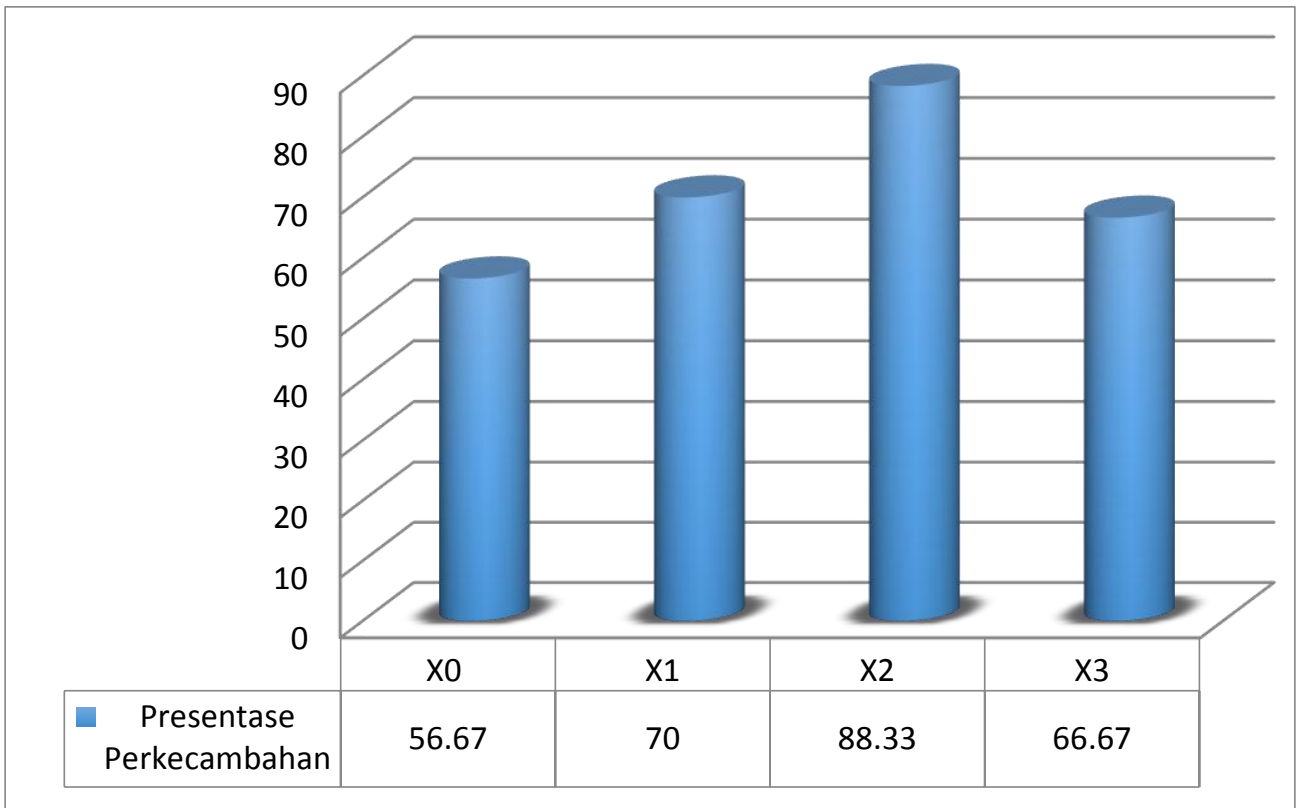

Keterangan:

Gambar 1. Presentase Perkecambahan Biji Cabai Rawit Pada Berbagai Perlakuan

$\mathrm{X}_{0}=$ Kontrol (tanpa penyimpanan)

$\mathrm{X}_{1}=$ lama penyimpanan 3 hari

$\mathrm{X}_{2}=$ lama penyimpanan 6 hari

$\mathrm{X}_{3}=$ lama penyimpanan 9 hari

Presentase perkecambahan biji cabai rawit pada lama penyimpanan, yang menunjuhkan adanya perlakuan tertentu yang berpengaruh sangat nyata pada lama waktu penyimpanan 6 hari. Tabel diatas menunjukan berbagai perlakuan yang mempunyai nilai presentase optimal pada perlakuan $\left(\mathrm{X}_{2}\right)$ dengan nilai presentase $(88,33333 \%)$, dan perlakuan lama penyimpanan 3 hari $\left(X_{1}=70\right), 9$ hari $\left(X_{3}=66,66667 \%\right)$ kemudian pada perlakuan $\left(\mathrm{X}_{0}\right)$ mempunyai nilai presentase terendah dengan nilai $(56,66667 \%)$.

\section{Laju perkecambahan biji cabai rawit}

Hasil perhitungan laju perkecambahan biji cabai rawit pada berbagai perlakuan dapat dilihat pada tabel berikut

Tabel 3. Laju perkecambahan biji cabai rawit (Jumlah kecambah/hari) pada berbagai lama penyimpanan

\begin{tabular}{|c|c|c|c|c|c|}
\hline & \multicolumn{3}{|c|}{ Kelompok } & Jumlah (\%) & \multirow{2}{*}{ Rata-rata\% } \\
\hline $\mathrm{X}_{0}$ & $\mathrm{I}$ & $\mathrm{II}$ & III & & \\
\hline $\mathrm{X}_{1}$ & 0,75 & $0 ., 394$ & 0,364 & 1,508 & 0,502667 \\
\hline $\mathrm{X}_{2}$ & 0,471 & 0,452 & 0,48 & 1,403 & 0,467667 \\
\hline $\mathrm{X}_{3}$ & 0,536 & 0,607 & 0,529 & 1,672 & 0,557333 \\
\hline Total & 0,456 & 0,444 & 0,452 & 1,352 & 0,450667 \\
\hline
\end{tabular}

Sumber: data hasil penelitian

Berdasarkan tabel tersebut, menunjukan adanya laju perkecambahan biji cabai rawit pada berbagai perlakuan lama penyimpanan. Jumlah laju perkecambahan dari berbagai perlakuan yang diurut dari yang tertinggi sampai yang terendah, $X_{2}$ $(0,557333 \%), X_{0}(0,502667 \%), X_{1}(0,467667 \%), X_{3}(0,450667 \%)$. Hal ini menunjukan 
bahwa pada lama penyimpanan 6 hari lebih cepat laju perkecambahan dibandingkan lama penyimpanan 0 hari, 3 hari dan 9 hari

Hasil penelitian lama penyimpanan terhadap presentase perkecambahan biji cabai rawit, jika dianalisis dengan mengunakan analisis sidik ragam, maka akan mendapatkan hasil seperti terihat pada tabel berikut di bawah ini:

Tabel 4. Hasil analisis sidik ragam persentase perkecambahan biji cabai rawit pada waktu penyimpanan.

\begin{tabular}{|c|c|c|c|c|c|c|}
\hline \multirow{2}{*}{ SK } & \multirow{2}{*}{ DB } & \multirow{2}{*}{$\mathrm{JK}$} & \multirow{2}{*}{ KT } & \multirow{2}{*}{ FH } & \multicolumn{2}{|c|}{ F. Tabel } \\
\hline & & & & & 0,05 & 0,01 \\
\hline Kelompok & 2 & 16,66667 & 8,33333 & 0,27 & & \\
\hline Perlakuan & 3 & 1091,667 & 363,889 & $11,91^{* *}$ & 4,76 & 9,78 \\
\hline Galat & 6 & 183,3333 & 30,55555 & & & \\
\hline Total & 11 & 1291,666667 & & & & \\
\hline
\end{tabular}

$\mathrm{KK}=7,99 \%$ Keterangan $: * *=$ sangat nyata karena $\mathrm{F}_{\text {hitung }}>\mathrm{F}_{\text {tabel }} 1 \%$

Berdasarkan hasil analisis sidik ragam pada tabel tersebut, menunjukan adanya perbedaan pengaruh yang sangat nyata pada lama penyimpanan terhadap presentase perkecambahan biji cabai rawit yang ditandai dengan $F_{\text {hitung }} 11.91$ dan $F_{\text {tabel }}$ 4,76 (5\%), 9,78 (1\%). Kemudian berdasarkan nilai KK (7,99\%) yang diperoleh maka untuk mengetahui perbadaan antara perlakuan digunakan analisis Uji Beda Nyata Jujur (BNJ) dan hasil uji dilihat pada tabel berikut

Tabel 5. Hasil uji BNJ

\begin{tabular}{|c|c|c|c|}
\hline Perlakuan & Rata - rata\% & $\mathrm{BNJ}_{0.05}$ & $\mathrm{BNJ}_{0.01}$ \\
\hline $\mathrm{X}_{0}$ & 56,66667 & $\mathrm{~b}$ & $\mathrm{~B}$ \\
\hline $\mathrm{X}_{1}$ & 70 & $\mathrm{ab}$ & $\mathrm{ab}$ \\
\hline $\mathrm{X}_{2}$ & 83,3333 & $\mathrm{a}$ & $\mathrm{a}$ \\
\hline $\mathrm{X}_{3}$ & 66,66667 & $\mathrm{~b}$ & $\mathrm{~b}$ \\
\hline $\mathrm{BNJ}_{0.05}=15,62$ & & & \\
$\mathrm{BNJ}_{0.01}=22,43$ & & & \\
\hline
\end{tabular}

Keterangan: Angka-angka yang diikuti oleh huruf yang sama berarti tidak berbeda nyata

Hasil uji BNJ pada Tabel 5, menunjukkan bahwa rata-rata persentase perkecambahan biji cabai rawit tertinggi $(83,3333 \%)$ terdapat pada perlakuan 6 hari penyimpanan (X2) dan tidak berbeda nyata dengan perlakuan 3 hari penyimpanan (X1), namun berbeda nyata dengan perlakuan kontrol (X0) dan perlakuan 9 hari penyimpanan (X3). Rata-rata persentase perkecambahan biji cabai rawit terendah $(56,66667 \%)$ terdapat pada perlakuan kontrol (X0) dan tidak berbeda nyata dengan perlakuan 9 hari penyimpanan (X3) dan perlakuan 3 hari penyimpanan (X1), tetapi berbeda nyata dengan perlakuan 6 hari penyimpanan (X2).

Hasil penelitian Pengaruh lama penyimpanan terhadap perkecambahan biji cabai rawit (Capsicum frutescens L), jika dianalisa dengan mengunakan Analisis sidik ragam, maka akan mendapatkan hasil seperti terlihat pada tabel dibawah ini. 
Tabel 6. Hasil analisis sidik ragam laju perkecambahan biji cabai rawit pada berbagai lama penyimpanan

\begin{tabular}{|c|c|c|c|c|c|c|}
\hline & & & & & \multicolumn{2}{|c|}{} \\
SK & DB & JK & KT & FH & \multicolumn{2}{|c|}{ F. Tabel } \\
\cline { 4 - 7 } & & & & & 0,05 & 0,01 \\
\hline Kelompok & 2 & 0,21299 & 0,01065 & 0,85 & & \\
Perlakuan & 3 & 0,019968 & 0,006656 & $0,53^{\text {th }}$ & 4,76 & 9,78 \\
Galat & 6 & 0,07512 & 0,01252 & & & \\
\hline Total & 11 & 0,116387 & & & & \\
\hline
\end{tabular}

$\mathrm{KK}=22,62 \%: \mathrm{F}_{\text {hitung }}<\mathrm{F}_{\text {tabel }}$

Keterangan $: \operatorname{tn}=$ Tidak Nyata

Berdasarkan tabel 8 tersebut, tidak menunjukan perbedaan pengaruh yang sangat nyata maupun nyata terhadap berbagai lama waktu penyimpanan terhadap laju perkecambahan biji cabai rawit yang ditandai dengan perlakuan yang mempunyai nilai tertinggi pada $\mathrm{F}$ hitung 0,58 yang lebih kecil dari $\mathrm{F}$ tabel pada $\alpha_{0,01}, 9,78$ dengan nilai Koefisien kerangaman sebesar 22,6237\% yang berarti tidak perlu diuji lanjut.

\section{Presentase perkecambahan biji cabai rawit}

Hasil analisis sidik ragam dan Uji BNJ menunjukan bahwa lama penyimpanan biji cabai rawit selama 6 hari berpengaruh sangat nyata terhadap presentase perkecambahan yang ditandai dengan $\mathrm{F}_{\text {hitung }} 11.91$ dan $\mathrm{F}_{\text {tabel }} 4,76$ (5\%), 9,78 (1\%). Hal ini membuktikan pula bahwa lama penyimpanan selama 6 hari dapat mematahkan dormansi fisik pada kulit biji cabai rawit yang merupakan penghambat mekanisme terhadap masuknya air dan gas ke dalam embrio biji. Perkecambahan benih yang tertunda, bukanlah merupakan suatu kebetulan tetapi sebagai hasil dari suatu mekanisme yang menyebabkan dalam keadaan yang tidak berkecambah (Dormansi). Suatu sebab yang sering dijumpai adalah kulit biji yang keras. Kulit biji yang keras ini dapat menyebabkan biji kedap air dan gas-gas serta menghambat perkecambahan. Benih selama satu atau dua minggu bahkan sampai beberapa bulan (Siginingsih, 2014).

Untuk mendapatkan perkecambahan yang baik harus memperhatikan faktotfaktor yang mempengaruhi perkecambahan. Proses perkecambahan biji merupakan suatu rangkaian kompleks dari perubahan morfologi, fisiologi dan biokimia. Tahap pertama dimulai dari penyerapan air oleh biji, melunakan kulit biji, dan hidrasi oleh protoplasma. Tahapan kedua dimulai dengan kegiatan sel dan enzim-enzim serta naiknya tingkat respirasi biji.Tahapan ketiga berupa penguraian bahan-bahan seperti karbohidrat, lemak, dan protein menjadi bentuk terlarut dan ditranslokasikan ke titik-titik tumbuh.Tahapan ke empat adalah asimilasi dan bahan bahan yang telah diuraikan di daerah enzimatik ke daerah meristimatik untuk menghasilkan energi untuk membentuk komponen dan pertumbuhan sel sel baru. Tahapan kelima adalah pertumbuhan kecambah melalui proses pembelaan dan pembesaran. 
Pada saat daun belum berfungsi untuk fotosintesis, maka pertumbuhan kecambah sangat bergantung pada persediaan makanan didalam biji. Pada tipe dormansi ini juga didapatkan tipe kulit biji yang dapat dilalui oleh air dan oksigen, tetapi perkembangan embrio terhalang oleh kekuatan mekanisme dari kulit biji. Cara untuk mengatasi dormansi yang disebabkan kulit biji yang keras ialah dengan memberikan perlakuan mekanisme tertentu dengan jalan mengusahakan agar kulit biji pecah atau lemah, sehingga memudahkan penyerapan air dan gas-gas secara efektif yang dibutuhkan oleh biji untuk berkecambah. Jika lama penyimpanan diatas 9 hari dan posisi persemaian yang salah dapat merusak embrio dan kotiledon mati karena masak dan perkecambahan kurang baik. Hal ini dapat dilihat pada pengamatan biji yang disimpanan selama 9 hari pada penelitian ini presentase perkecambahan menurun, sebagai mana dilihat pada presentase yaitu $(66,66667 \%)$ bila dibandingkan dengan penyimpanan selama 6 hari $(88,3333 \%)$. Lebih jelasnya dapat dilihat pada tabel presentase.

Adanya perbedaan perlakuan pengaruh perlakuan skarifikasi benih terhadap persen perkecambahan diduga disebabkan perbedaan respon kulit biji terhadap perlakuan skarifikasi biji. Perlakuan skarifikasi benih meningkatkan presentase perkecambahan pada dasarnya adalah dengan merusak biji yang keras sehingga air dan oksigen mudah masuk ke dalam biji

\section{Laju perkecambahan biji cabai rawit}

Laju perkecambahan merupakan suatu aspek penting dari vigor tanaman. Salah satu pengujian untuk menilai laju perkecambahan dapat dilakuan dengan mengunakan indeks vigor (jumlah kecambah/hari). Pada perlakuan berbagai lama waktu penyimpanan, tidak memberi pengaruh pada laju perkecambahan. Sebagaimana pada penelitian ini diperoleh nilai $F_{\text {hitung }}$ lebih kecil dari $F_{\text {tabel }}$ dengan nilai $F_{\text {hitung }}(0,53)$ bila dibandingkan dengan nilai $\mathrm{F}_{\text {tabel }}(5 \%)$ 4,76 dan taraf (1\%) 9,78. Pada tabel ansira laju perkecambahan menunjukan tidak ada pengaruh perlakuan terhadap laju perkecambahan.

Posisi tanam benihnya ditanam dalam posisi $30^{\circ}$ dan mikrofilnya ke atas maka terjadinya penyerapan air yang lebih banyak dibandingkan dengan posisi benih dengan mikrofilnya kebawah. Posisi mikrofil dan bagian biji yang mudah dilalui molekul air sangat menentukan jumlah air yang diserap biji melalui proses imbibisi. Pada posis $30^{\circ}$ dengan posisi mikrofil ke atas memberikan peluang penyerapan air oleh biji lebih banyak dikarenakan posisi mikrofil dan bagian tengah (belahan) kulit dibagian vigorsitas benih dipengaruhi oleh posisi benih saat penanaman.

Pengaruh lama penyimpanan benih sangat berpengaruh nyata terhadap kecepatan berkecambah, yang mencerminkan kecepatan semai muncul dipermukaan media tanam. Perhitungan kecepatan berkecambah dilakukan setelah semai nampak dipermukaan tanah sebagai media tumbuh, yaitu pada stadia pancing. Kecepatan atau saat muncul stadia pancing inilah yang dipengaruhi oleh posisi benih saat penanaman, hal ini diduga posisi tanam sangat mempengaruhi perkecambahan. bahwa, posisi tanam benih sangat 
mempengaruhi posisi lubang mikrofil biji maupun bagian kulit ventral akan sangat menentukan jumlah air (kelembaban) yang dapat diserap oleh biji, karena melalui bagian biji tersebut air mudah terserap ke dalam benih.

\section{KESIMPULAN}

1. Terdapat pengaruh lama penyimpanan terhadap perkecambahan biji cabai rawit.

2. Sangat besar pengaruh lama penyimpanan terhadap perkecambahan biji cabai rawit.

\section{SARAN}

1. Dalam meningkatkan presentase perkecambahan dengan alternative terbaik untuk perlakuan tunggal adalah melakukan perlakuan lama waktu penyimpanan 6 hari

2. Direkomendasikan kepada para petani cabai untuk meningkatkan benih yang baik maka perlu dilakuan perlakuan penyimpanan benih selama 6 hari untuk mendapatkan hasil yang maksimal.

\section{DAFTAR PUSTAKA}

Almatsier, S. 2004. Prinsip Dasar Ilmu Gizi. Jakarta: PT Gramedia Pustaka Utama.

Bambang B, Santoso, Hariyadi, Bambang S Purwoko. 2004. Tinjauan Argo-Morfologi Perkecambahan Biji Jarak Pagar. Jurnal Penelitian UNRAM, hlm 8-9

Husna Amien. 2007. Bercocok Tanam Cabai Rawit, Merah dan Cabai Merah dan Cabai Jawa. Jakarta: SCA.

Ihsanul Arifin. 2010. pengaruh cara dan lama penyimpanan terhadap mutu cabai rawit capsicum Frutencens L var. Cengek. Malang: UIN Maulana Malik Ibrahim.

Setijo Pitojo. 2003. Benih Cabai. Yogyakarta: Kanisius.

J.s Badudu dan Sultan Mohammad Zain. 1994. Kamus Umum Bahasa Indonesia. Jakarta: Pustaka Sinar Harapan.

Kuswanto, H. 1996. Dasar-Dasar Teknologi Produksi dan Sertifikasi Benih. Jakarta: Offset.

Nurul Sumiasri, Ninik Setyowati. 2010. Pengaruh beberapa media pada pertumbuhan bibit eboni (diospyros celebica bahk) melalui pembayakan biji (jurnal Online).

Nunik Larasati, http;//blog.uad.ac.id/2011/12/15/tipe perkecambahan epgeal dan hypogeal, di akses tgl 01-08-2011.

Paimin, F.R. 1994. Kemiri Budidaya dan Prospek Benih. Jakarta: Penebar Swaday.

Setijo Pitojo. 2003. Benih Cabai. Yogyakarta: Penerbit Kanisus

Suginingsih. 2013. Pengaruh Perlakuan Awal Terhadap kecepatan perkecambahan dan prosentase kecambah benih kemiri.(Jurnal Online) Diakses pada tangga), rabu, tanggal, 6-3-2014.

Sukarma Dkk. 2010. Pengaruh Penderaan Dan Suhu Perkecambahan Terhadap Viabilitas Benih Jambu Mente. Jurnal Online. 
JURNAL BIOLOGY SCIENCE \& EDUCATION 2017 IRWAN.S DKK

T. Sarpian. 2007. Bertanam Cabai Rawit Dalam Polybag. Jakarta: Penebar Swadaya. 